\title{
Understanding the Adoption of Mobile Internet in the Saudi Arabian Context: Results from a Descriptive Analysis
}

\author{
Abdullah Baabdullah ${ }^{1}$, Yogesh Dwivedi ${ }^{1}$, Michael Williams ${ }^{1}$, and Prabhat Kumar ${ }^{2}$ \\ ${ }^{1}$ Management and Systems Section (MaSS), School of Management, Swansea University, \\ Swansea, SA2 8PP, UK \\ $\{685177$, y.k.dwivedi, m.d.williams\}@swansea.ac.uk \\ ${ }^{2}$ Department of Computer Science and Engineering, National Institute of Technology, \\ Patna, India \\ prabhat@nitp.ac.in
}

\begin{abstract}
Utilising Mobile Internet (M-Internet) services would increase socioeconomic benefits. Hence, it is necessary to consider the factors that may increase the adoption of M-Internet services within the context of Saudi Arabia. This research aims to examine potential users' intentions towards different variables that may be significant for supporting higher usage of M-Internet services in the domain of the Kingdom of Saudi Arabia. This study embraces the following variables: perceived risk, innovativeness; performance expectancy, effort expectancy, social influence, facilitating conditions, perceived value, hedonic motivation and behavioural intention. Data was collected by means of a questionnaire on a convenience sample that consisted of 600 subjects with a response rate of $69.5 \%$. The findings gathered from a descriptive analysis suggested that the related variables are perceived as significant by participants and they have strong behavioural intention to use MInternet services.
\end{abstract}

Keywords: Saudi Arabia, M-Internet, UTAUT2, perceived risk, innovativeness

\section{Introduction}

The importance of studying M-Internet within the context of Saudi Arabia is derived from the statistics that the Kingdom has experienced considerable growth of marketplaces in Information and Communication Technology (ICT) in the Middle East; predominantly in the retail and financial services' sectors as well as domestic broadband penetration (STC Group, 2011). For example, between 2005 and 2011, domestic broadband penetration had risen from zero to $44 \%$ and M-Internet penetration had increased from $60 \%$ to $191 \%$ over the same period [32]. The statistics of using various types of M-Internet services in Saudi Arabia refers to the growth in the adoption of this new technology in areas such as M-Advertising. For example, in 2010, it reached a compound annual growth of $31 \%$ according to Analysys Mason [6]. Also, the number of M-Internet users in Saudi Arabia had reached 11.5 million at the 
end of 2011 representing $40.5 \%$ of the population [18]. However, the adoption of other types of M-Internet in Saudi Arabia is still in its early stage. For example, only $39 \%$ of M-Internet users in Saudi Arabia used this service for commercial purposes in 2011 [6]. Indeed, enhancing the level of behavioural intention toward using MInternet in Saudi Arabia is a challenging task especially in the business arena due to the strong presence of cultural and technological parameters [6]. Tackling the factors that might predict behaviour intention towards using M-Internet among potential users will have a positive impact on raising the rate of using M-Internet across the Kingdom. This research will consider performance expectancy, effort expectancy, social influence, facilitating conditions, perceived value, hedonic motivation, perceived risk and innovativeness as probable predictors of behavioural intention amongst potential adopters of M-Internet in the domain of Saudi Arabia. By doing this research, this study will pinpoint the factors that can predict behaviour intention of M-Internet and thereby enhancing the use of M-Internet in the Saudi Arabian context. This paper is structured as follows: section two mentions an overview of MInternet literature; then the researchers will give an overview of the theoretical basis in the third section. Next, methodology, results and discussion are outlined in the fourth, fifth and sixth sections respectively. In section seven, this study gives a synopsis.

\section{Literature Review}

Defining M-Internet is quite important before having any theoretical or empirical discussion as there are a lot of mobile strands that have different characteristics [11]. M-Internet can be defined as the "access to the Internet with devices that offer wireless connectivity" [20]. M-Internet relies on the three interconnected elements: the mobile device, a mobile network, and mobile content [20]. Consequently, the MInternet makes a world where everyone can be connected regardless of time and space [24]. These distinctive traits, and their link to M-Internet, have generated an extraordinary level of M-Internet adoption worldwide. Indeed, there are plenty of studies that have focused on studying M-Internet (e.g. [7], [24], [26]. Within the context of Saudi Arabia, Alwahaishi and Snášel [4], [5] provided their new framework to pinpoint variables that might affect the acceptance of M-Internet and use in Saudi Arabia. Nonetheless, M-Internet reluctance can be attributed to different factors such as the lack of widespread use of mobile phones [38] and inaccessibility of the technological support [13]. However, within the context of Saudi Arabia and from 2004, use of the M-Internet has grown due to the development in wireless technology which led to a number of advantages such as discarding the need for landlines; minimising repetitive software installations; and solving the problem of temporary loss of high-speed Internet in some areas through using mobile devices [6]. Nevertheless, this advancement of M-Internet in Saudi Arabia has recorded a lower level compared with neighbouring countries such as Kuwait, UAE and Qatar. As such, a study was held in 2010 about the broadband subscriptions by using MInternet, and found that mobile subscriptions in Qatar, UAE, Kuwait, Saudi Arabia were $72 \%, 68 \%, 65 \%$ and $42 \%$ respectively [9]. The adoption of M-Internet in Saudi Arabia still lags behind neighbouring states for many reasons such as network problems; that is to say, wireless access is limited in remote areas in Saudi Arabia. 
Furthermore, even if there was access, frequent network problems have been recorded. According to a study conducted by Analysys Mason [9] in Saudi Arabia, it showed that there is a need to "harmonise the mobile broadband spectrum" in the "700/800 and 2.6 GHz bands for the use by mobile operators." As M-Broadband refers to Internet access (wireless communications) that has taken the place of a mobile phone, this shortage impacts negatively on the mobile broadband services and eventually on M-Internet services[9]. Although the adoption of M-Internet services has experienced a permanent growth in the Saudi context, the magnitude of this growth is still modest when compared with other states. According to the STC Group [32] regarding individual/household purchasing on the Internet in 2009 by either using the M-Internet or a fixed Internet, Saudi Arabia was way behind the UK and Norway with $2 \%, 66 \%$, and $70 \%$ respectively; Saudi Arabia are also behind Italy $(12 \%)$ and Greece $(10 \%)$. Interestingly, this modest adoption of M-Internet amongst Saudi citizens was in contrast with the huge increase in the budget of the Saudi telecom sector. As such, in 2009, the per capita telecom investment in Saudi telecom exceeded US\$400m compared with US\$150m in the UK. This information is important to notice that although the telecom revolution industry which is the basis for any activity through M-Internet, the actual use of M-Internet services in Saudi Arabia was way behind the UK. These evidences suggest that M-Internet services have not been heavily used yet, and Saudi users have not yet perceived these services. So, this study will examine the factors that may affect the adoption of this technology by the potential users through examining the factors that might influence behaviour intention of the potential users towards using M-Internet in the Saudi context. The outcomes of this current paper will be as follows: this research will consider UTAUT2 factors as well as perceived risk (PR) and innovativeness (INN) to pinpoint accurately the variables that change the behavioural intention of Saudi potential users in order to use the M-Internet.

\section{Theoretical Basis}

The Unified Theory of Acceptance and Use of Technology (UTAUT) proposes to predict adopters' intentions to adopt IT. It embraces four variables: performance expectancy (PE), effort expectancy (EE), social influence (SI), and facilitating conditions (FC). In this theory, PE, EE, and SI are direct determinants of behavioural intention (BI) and actual usage, and $\mathrm{FC}$ is a direct determinant of actual usage. Venkatesh et al. [36] confirmed that UTAUT predicted $70 \%$ and $50 \%$ of the variances in BI and usage respectively. Furthermore, a considerable number of writers have applied UTAUT in order to predict BI and usage in the field of M-Internet (e.g. [4], [5], [26], [38]. The UTAUT has been internationally tested, modified and developed over the years in order to explain users' behaviour towards the adoption of the MInternet, e.g. Venkatesh et al. [35] adopted UTAUT and UTAUT2. Venkatesh et al. [35] developed UTAUT2 for investigating users' adoption of the M-Internet by extending UTAUT to UTAUT2 to bridge the void that occurred in the users' adoption domain. UTAUT2 adds new constructs: i.e. hedonic motivation (HM); price value (PV); and habit (HT) in addition to the UTAUT variables including PE, EE, SI, FC, $\mathrm{BI}$ and usage. The addition of these new variants gives more capability of estimation of the variables' intention to use compared with the UTAUT model. Moreover, in 
UTAUT2, association between FC and BI has been applied in order to offer a method to test the significance of $\mathrm{FC}$ in effecting $\mathrm{BI}$ of potential adopters in this study rather than testing the influence of FC over usage as applied in the UTAUT model. Thus, this paper holds UTAUT2 variables for examining the use of the M-Internet by potential adopters in the Saudi Arabian domain. UTAUT2 assembled factors of other models in order to offer a higher level of predictability about the behaviour of potential adopters when using the M-Internet. In detail, PE and EE in UTAUT2 replaced perceived usefulness and perceived ease of use in TAM respectively. FC in UTAUT2 interchanged with perceived behavioural control (PBC) in TPB [12]. Similarly, HM in UTAUT2 replaced the perceived enjoyment variable. Likewise, social impact in UTAUT2 is similar to subjective norm and family influence [35]. Finally, PV stands for price and cost [28]. Venkatesh et al. [35] suggested examining the appropriateness of the UTAUT2 in various contexts. This research adopts the UTAUT2 model factors in addition to two new factors: i.e. perceived risk (PR) and innovativeness (INN) to critically evaluate the impact of these factors over BI of the potential adopters [31]. After reviewing the literature [16], [37], this study will adopt a conceptual model that will consist of candidate variables that might highly affect the adoption of potential users of the M-Internet in the Saudi Arabian context [8]. In order to check these variables, this research followed a quantitative study [17]. Unlike UTAUT2, this study does not consider habit as an independent variable as well as usage as a dependent variable. The reason for not considering habit and usage lies in the fact that this study focuses on the potential user rather than the actual usage of the M-Internet. Hence, it discards actual usage. Furthermore, according to Venkatesh et al. [35], habit has a direct effect on usage; consequently, there is no need for considering the habit variable when not studying usage. The mentioned constructs are viewed in Table 1 as follows:

Table 1. Description of factors

\begin{tabular}{|c|c|c|}
\hline $\begin{array}{l}\text { Factor } \\
\text { Examined }\end{array}$ & Definition & $\begin{array}{l}\text { Example citations that have } \\
\text { tested this construct for } \\
\text { examining the adoption of } \\
\text { mobile applications }\end{array}$ \\
\hline $\begin{array}{l}\text { Performance } \\
\text { Expectancy (PE) }\end{array}$ & $\begin{array}{l}\text { "The degree to which using a } \\
\text { technology will provide benefits to } \\
\text { consumers in performing certain } \\
\text { activities" [34, p. 159] }\end{array}$ & {$[35],[36]$} \\
\hline $\begin{array}{l}\text { Effort } \\
\text { Expectancy (EE) }\end{array}$ & $\begin{array}{l}\text { "The degree of ease associated with } \\
\text { consumers' use of technology" [34, } \\
\text { p. 159] }\end{array}$ & {$[3],[34]$} \\
\hline $\begin{array}{l}\text { Facilitating } \\
\text { Conditions (FC) }\end{array}$ & $\begin{array}{l}\text { "Refer to consumers' perceptions of } \\
\text { the resources and support } \\
\text { available to perform a behaviour" } \\
{[34, \text { p. } 159]}\end{array}$ & {$[35],[40]$} \\
\hline $\begin{array}{l}\text { Social Influence } \\
\text { (SI) }\end{array}$ & $\begin{array}{l}\text { "The extent to which consumers } \\
\text { perceive that important others (e.g. } \\
\text { family and friends) believe they } \\
\text { should use a particular technology" } \\
{[34, \text { p. 159] }}\end{array}$ & {$[25],[35]$} \\
\hline Hedonic & "The fun or pleasure derived from & {$[33],[35]$} \\
\hline
\end{tabular}




\begin{tabular}{|c|c|}
\hline $\begin{array}{l}\text { Motivation } \\
\text { (HM) }\end{array}$ & $\begin{array}{l}\text { using technology and it has been } \\
\text { shown to play an important role in } \\
\text { determining technology acceptance } \\
\text { and use" [9, p. } 402]\end{array}$ \\
\hline $\begin{array}{l}\text { Price Value } \\
\text { (PV) }\end{array}$ & $\begin{array}{l}\text { "Consumers' cognitive trade-off } \\
\text { between the perceived benefits of the } \\
\text { applications and the monetary cost } \\
\text { for using them" [34, p. 161] }\end{array}$ \\
\hline $\begin{array}{l}\text { Innovativeness } \\
\text { (INN) }\end{array}$ & $\begin{array}{l}\text { "The willingness of an individual to } \\
\text { try out any new information } \\
\text { technology" [40, p. 229] }\end{array}$ \\
\hline $\begin{array}{l}\text { Perceived Risk } \\
\text { (PR) }\end{array}$ & $\begin{array}{l}\text { "The expectation of losses associated } \\
\text { with purchase and acts as an } \\
\text { inhibitor to purchase behaviour" [19, } \\
\text { p. } 454]\end{array}$ \\
\hline $\begin{array}{l}\text { Behaviour } \\
\text { Intention (BI) }\end{array}$ & $\begin{array}{l}\text { "The intention of the user to use the [35]. [39] } \\
\text { technology" }[39, \text { p. 160] }\end{array}$ \\
\hline
\end{tabular}

\section{Methodology}

According to Table 2, this research tests nine variables: i.e. INN, PR, PE, EE, SI, FC, $\mathrm{HM}, \mathrm{PV}$ and BI. It refers to the writers to whom this study relies on when considering 35 items. The level of responses was measured by implementing the seven-point Likert scale. Regarding demographic variables, this research embraces gender, age, education, occupation and monthly income. The researchers employed convenience sampling in three cities: i.e. Jeddah, Riyadh and Dammam.

Table 2. Scale items of the selected factors

\begin{tabular}{|c|c|c|}
\hline Construct & Item & Source \\
\hline \multirow{4}{*}{$\begin{array}{l}\text { Performance } \\
\text { Expectancy (PE) }\end{array}$} & PE1. M-Internet will be useful in my daily life. & \multirow[t]{11}{*}[35]{} \\
\hline & $\begin{array}{l}\text { PE2. Using M-Internet will help me } \\
\text { accomplish things more quickly. }\end{array}$ & \\
\hline & $\begin{array}{l}\text { PE3. Using M-Internet will increase my } \\
\text { productivity. }\end{array}$ & \\
\hline & $\begin{array}{l}\text { PE4. Using M-Internet will increase my } \\
\text { chances of achieving things that are important } \\
\text { to me. }\end{array}$ & \\
\hline \multirow[t]{4}{*}{$\begin{array}{l}\text { Effort Expectancy } \\
\text { (EE) }\end{array}$} & $\begin{array}{l}\text { EE1. Learning how to use M-Internet will be } \\
\text { easy for me. }\end{array}$ & \\
\hline & $\begin{array}{l}\text { EE2. My interaction with M-Internet will be } \\
\text { clear and understandable. }\end{array}$ & \\
\hline & EE3. M-Internet will be easy to use. & \\
\hline & $\begin{array}{l}\text { EE4. It will be easy for me to become skilful at } \\
\text { using M-Internet. }\end{array}$ & \\
\hline \multirow[t]{3}{*}{$\begin{array}{l}\text { Social Influence } \\
\text { (SI) }\end{array}$} & $\begin{array}{l}\text { SI1. People who are important to me think that } \\
\text { I should use M-Internet. }\end{array}$ & \\
\hline & $\begin{array}{l}\text { SI2. People who influence my behaviour think } \\
\text { that I should use M-Internet. }\end{array}$ & \\
\hline & $\begin{array}{l}\text { SI3. People, whose opinions that I value, } \\
\text { prefer that I use M-Internet. }\end{array}$ & \\
\hline
\end{tabular}




\begin{tabular}{|c|c|c|}
\hline \multirow[t]{4}{*}{$\begin{array}{l}\text { Facilitating } \\
\text { Conditions (FC) }\end{array}$} & $\begin{array}{l}\text { FC1. I have the resources necessary to use M- } \\
\text { Internet. }\end{array}$ & \\
\hline & $\begin{array}{l}\text { FC2. I have the knowledge necessary to use } \\
\text { M-Internet. }\end{array}$ & \\
\hline & $\begin{array}{l}\text { FC3. M-Internet is compatible with other } \\
\text { technologies I use. }\end{array}$ & \\
\hline & $\begin{array}{l}\text { FC4. I can get help from others when I have } \\
\text { difficulties using M-Internet. }\end{array}$ & \\
\hline \multirow{3}{*}{$\begin{array}{l}\text { Hedonic } \\
\text { Motivation (HM) }\end{array}$} & HM1. Using M-Internet will be fun. & \\
\hline & HM2. Using M-Internet will be enjoyable. & \\
\hline & $\begin{array}{l}\text { HM3. Using M-Internet will be very } \\
\text { entertaining. }\end{array}$ & \\
\hline \multirow[t]{3}{*}{ Price Value (PV) } & PV1. M-Internet is reasonably priced. & \\
\hline & PV2. M-Internet is good value for the money. & \\
\hline & $\begin{array}{l}\text { PV3. At the current price, M-Internet provides } \\
\text { good value. }\end{array}$ & \\
\hline \multirow[t]{5}{*}{$\begin{array}{l}\text { Perceived Risk } \\
\text { (PR) }\end{array}$} & $\begin{array}{l}\text { PR1. Providing M-Internet service with my } \\
\text { personal information would involve many } \\
\text { unexpected problems. }\end{array}$ & [40] \\
\hline & $\begin{array}{l}\text { PR2. It would be risky to disclose my personal } \\
\text { information through this service provider. }\end{array}$ & \\
\hline & $\begin{array}{l}\text { PR3. There would be high potential for loss in } \\
\text { disclosing my personal information to this } \\
\text { service provider. }\end{array}$ & \\
\hline & $\begin{array}{l}\text { PR4. Using M-Internet services subjects your } \\
\text { checking account to financial risk. }\end{array}$ & [19] \\
\hline & $\begin{array}{l}\text { PR5. I think using M-Internet puts my privacy } \\
\text { at risk. }\end{array}$ & [39] \\
\hline \multirow[t]{6}{*}{$\begin{array}{l}\text { Innovativeness } \\
\text { (INN) }\end{array}$} & $\begin{array}{l}\text { INN1. If I heard about M-Internet technology, } \\
\text { I would look for ways to experiment with it. }\end{array}$ & [27] \\
\hline & $\begin{array}{l}\text { INN2. Among my peers, I am usually the first } \\
\text { to explore new technologies. }\end{array}$ & \\
\hline & $\begin{array}{l}\text { INN3. I like to experiment with new } \\
\text { technologies: i.e. M-Internet. }\end{array}$ & \\
\hline & $\begin{array}{l}\text { INN4. In general, I am not hesitant to try out } \\
\text { new information technologies. }\end{array}$ & {$[1]$} \\
\hline & $\begin{array}{l}\text { INN5. Compared to my friends, I seek out a lot } \\
\text { of information about M-Internet services. }\end{array}$ & [2] \\
\hline & $\begin{array}{l}\text { INN6. I would try the new M-Internet service } \\
\text { even if, in my circle of friends, nobody has } \\
\text { trialled it before. }\end{array}$ & \\
\hline \multirow{3}{*}{$\begin{array}{l}\text { Behavioural } \\
\text { Intention (BI) }\end{array}$} & BI1. I will use M-Internet in the future. & [35] \\
\hline & $\begin{array}{l}\text { BI2. I will always try to use M-Internet in my } \\
\text { daily life. }\end{array}$ & \\
\hline & BI3. I will plan to use M-Internet frequently. & \\
\hline
\end{tabular}




\section{Results}

\subsection{Response Rate}

Table 3 outlines the distributed sample for M-Internet technology, returned responses, incomplete and problematic responses, and finally valid responses.

Table 3. Response Rate

\begin{tabular}{lll}
\hline & \multicolumn{1}{c}{ M-Internet } & \multicolumn{1}{c}{} \\
\hline Sample & 600 & 100 \\
\hline Returned responses & 436 & 72.67 \\
\hline Incomplete and problematic responses & 19 & 3.17 \\
\hline Valid responses & 417 & 69.5 \\
\hline
\end{tabular}

\subsection{Respondents' Profile and Characteristics}

Table 4 below shows thedemographic characteristics of M-Internet respondents:

Table 4. Respondents' profile and characteristics

Demographic Profile
Percentage

(\%)

\begin{tabular}{lcc}
\hline Gender & & \\
\hline Male & 247 & 59.2 \\
\hline Female & 170 & 40.8 \\
\hline Total & 417 & 100 \\
\hline Age & & \\
\hline$>=18-20$ & 55 & 13.2 \\
\hline $21-29$ & 242 & 58 \\
\hline $30-39$ & 68 & 16.3 \\
\hline $40-49$ & 33 & 7.9 \\
\hline 50 and above & 19 & 4.6 \\
\hline Total & 417 & 100 \\
\hline Education & & 3.4 \\
\hline Less than High & 14 & 18.5 \\
School & & 17.7 \\
\hline High School & 77 & 45.8 \\
\hline Diploma & 74 & 14.6 \\
\hline Bachelor & 191 & 100 \\
\hline Postgraduate & 61 &
\end{tabular}

Occupation 


\begin{tabular}{lcc} 
Student & 53 & 12.7 \\
\hline $\begin{array}{l}\text { Government } \\
\text { employee }\end{array}$ & 218 & 52.3 \\
\hline $\begin{array}{l}\text { Private sector } \\
\text { employee }\end{array}$ & 97 & 23.3 \\
\hline Self employed & 49 & 11.8 \\
\hline Total & 417 & 100.1 \\
\hline Monthly income (Saudi Riyals) & 36 & 8.6 \\
\hline $1000-4000$ & 91 & 21.8 \\
\hline $4001-8000$ & 183 & 43.9 \\
\hline $8001-14000$ & 73 & 17.5 \\
\hline $14001-20000$ & 34 & 8.2 \\
\hline More than 20000 & 417 & 100
\end{tabular}

\subsection{Respondents' Profile and Characteristics}

According to Table 5, the average mean score and standard deviation were calculated for studied constructs as well as for items of these constructs.

Table 5. Descriptive analysis of measurement items

\begin{tabular}{llcc}
\hline Construct & Item & Mean & Standard Deviation \\
\hline Performance Expectancy & PE1 & 6.66 & .566 \\
\hline & PE2 & 6.67 & .563 \\
\hline & PE3 & 6.64 & .590 \\
\cline { 2 - 4 } & PE4 & 6.67 & .573 \\
\cline { 2 - 4 } Effort Expectancy & Average & 6.66 & .573 \\
\hline \multirow{5}{*}{ Social Influence } & EE1 & 6.56 & .641 \\
\hline & EE2 & 6.61 & .591 \\
\cline { 2 - 4 } & EE3 & 6.56 & .641 \\
\cline { 2 - 4 } & EE4 & 6.57 & .624 \\
\cline { 2 - 4 } & Average & 6.60 & .583 \\
\hline Facilitating Conditions & SI1 & 6.47 & .686 \\
\hline \multirow{2}{*}{ SI2 } & 6.47 & .672 \\
\cline { 2 - 4 } & SI3 & 6.46 & .696 \\
\cline { 2 - 4 } & Average & 6.46 & .684 \\
\hline Hedonic Motivation & FC1 & 6.45 & .671 \\
\hline & FC2 & 6.46 & .678 \\
\cline { 2 - 4 } & FC3 & 6.45 & .885 \\
\cline { 2 - 4 } & FC4 & 6.20 & .72 \\
\cline { 2 - 4 } & Average & 6.39 & .403 \\
\hline
\end{tabular}




\begin{tabular}{|c|c|c|c|}
\hline & HM2 & 6.81 & .408 \\
\hline & HM3 & 6.82 & .401 \\
\hline & Average & 6.81 & .404 \\
\hline \multirow[t]{4}{*}{ Price Value } & PV1 & 6.01 & .732 \\
\hline & PV2 & 5.97 & .751 \\
\hline & PV3 & 5.96 & .770 \\
\hline & Average & 5.98 & .751 \\
\hline \multirow[t]{7}{*}{ Innovativeness } & INN1 & 6.38 & .721 \\
\hline & INN2 & 5.50 & 1.312 \\
\hline & INN3 & 6.42 & .743 \\
\hline & INN4 & 6.52 & .676 \\
\hline & INN5 & 6.19 & .953 \\
\hline & INN6 & 6.46 & .710 \\
\hline & Average & 6.24 & .852 \\
\hline \multirow[t]{6}{*}{ Perceived Risk } & PR1 & 1.98 & .554 \\
\hline & PR2 & 1.94 & .547 \\
\hline & PR3 & 1.98 & .539 \\
\hline & PR4 & 2.04 & .589 \\
\hline & PR5 & 2.11 & .673 \\
\hline & Average & 2.01 & .580 \\
\hline \multirow[t]{4}{*}{ Behavioural Intention } & BI1 & 6.70 & .517 \\
\hline & $\mathrm{BI} 2$ & 6.71 & .514 \\
\hline & $\mathrm{BI} 3$ & 6.70 & .518 \\
\hline & Average & 6.70 & .516 \\
\hline
\end{tabular}

\section{Discussion}

The descriptive statistics gave mean and standard deviation for each related variable and its items. Generally speaking, reading the average mean and average standard deviation for each variable can be classified into one of these four categories: high mean and high standard deviation, low mean and low standard deviation, high mean and low standard deviation, and low mean and high standard deviation [14]. The related variables, i.e. PE, EE, SI, FC, HM, PV, INN and BI, had a high average mean and a low standard deviation within the accepted limits $( \pm 1 \mathrm{SD})$. The high mean, which is combined with the low standard deviation, indicated that the respondents' answers tended to be 'strongly agree' with a high certainty. In contrast, the low mean, which is combined with the low standard deviation, indicated that the respondents' answers tended to be 'strongly disagree' with a high certainty; i.e. perceived risk (PR) as participants seem to be less concerned regarding risks related to M-Internet services. Consequently, it is recommended that future studies should re-examine the significance level of each one of these variables to obtain a better prediction over the adoption of the M-Internet in the Saudi Arabian context. 


\subsection{Contribution}

Very few studies have been conducted in Saudi Arabia regarding M-Internet. This research has investigated statistically the variables that affect the BI towards adopting the M-Internet amongst potential adopters; thus, this study can suggest the best way to increase the BI of the potential users which is an essential step towards actually adopting the M-Internet. This research included PR and INN to establish a suggested gap in UTAUT2 that disregarded the empirical findings about the significance of these two variables. Indeed, this is compatible with Venkatesh et al. [35] who suggest investigating UTAUT2 applicability on the M-Internet in different countries.

\section{Conclusion}

This study attempts to pinpoint the various factors that are considered to be effective on the behavioural intention of potential users when it comes to using the M-Internet in Saudi Arabia. Nine variables were selected, i.e. PE, EE, SI, FC, HM, PV, PR, INN and BI. Through running a descriptive analysis for every variable after giving the questionnaire to the participants, the findings of the analysis indicated that the related factors are effective when it comes to the behavioural intention of the participants.

\subsection{Limitations and Future Research Directions}

First of all, it will not be possible to generalise the findings to be representative of the overall population in Saudi Arabia because of the employment of a descriptive analysis rather than an inferential one which depends on using a Structural Equation Modelling (SEM). As this study considers investigating the behaviour intention instead of the actual use of the M-Internet, it is not going to provide a complete view about the actual usage of this service in Saudi Arabia. Moreover, conducting a longitudinal research is going to provide a better understanding regarding M-Internet in addition to clarifying the effects of the variables under study whose effects are stable and lasting over time. Consequently, any future study has to take into account these issues.

\section{References}

1. Agarwal, R., Prasad, J.: A conceptual and operational definition of personal innovativeness in the domain of information technology. Information Systems Research, 9(2), 204-215 (1998).

2. Aldás-Manzano, J., Ruiz-Mafé, C., Sanz-Blas, S.: Exploring individual personality factors as drivers of $\mathrm{M}$-shopping acceptance. Industrial Management \& Data Systems, 109(6), 739-757 (2009).

3. Alkhunaizan, A., Love, S.: What drives mobile commerce? An empirical evaluation of the revised UTAUT model. International Journal of Management and Marketing Academy, 2(1), 82-99 (2012).

4. Alwahaishi, S., Snášel, V.: Consumers' acceptance and use of information and communications technology: A UTAUT and flow-based theoretical model. Journal of Technology Management \& Innovation, 8(2), 61-73 (2013a). 
5. Alwahaishi, S., Snášel, V.: Factors influencing the consumers' adoption of mobile Internet. In The Third International Conference on Digital Information and Communication Technology and its Applications DICTAP 2013. (pp. 31-39). The Society of Digital Information and Wireless Communication (2013b).

6. Analysys Mason.: Final Report to the GSMA: the Socio-Economic Benefit of Allocating Harmonised Mobile Broadband Spectrum in the Kingdom of Saudi Arabia. Available on: http://www.gsma.com/spectrum/wp-content/uploads/2012/05/ GSMA report on KSA DD2 6GHz 2012-04-30.pdf. Accessed: 01.02 .15 (2012).

7. Baabdullah, A. M., Dwivedi, Y. K., Williams, M. D.: IS/IT Adoption Research in the Saudi Arabian Context: Analysing Past And Outlining The Future Research Directions. European, Mediterranean, and Middle Eastern Conference on Information System (EMCIS2013). October 17-18 2013, Windsor, United Kingdom (2013).

8. Baabdullah, A. M., Dwivedi, Y. K., Williams, M. D.: Adopting an Extended UTAUT2 to Predict Consumer Adoption of M-Technologies in Saudi Arabia. UK Academy for Information Systems Conference Proceedings 2014.Paper 5 (2014).

9. Brown, S. A., Venkatesh, V.: A model of adoption of technology in the household: A baseline model test and extension incorporating household life cycle. Management Information Systems Quarterly, 29(3), 4 (2005).

10. Central Department of Statistics and Information.: Population Statistics. Available on: http://www.cdsi.gov.sa/english/index.php. Accessed: 17.01.15 (2014).

11. Chae, M., Kim, J.: What's so different about the mobile Internet? Communications of the ACM, 46(12), 240-247 (2003).

12. Chen, S. C., Li, S. H.: Consumer adoption of e-service: Integrating technology readiness with the theory of planned behavior. African Journal of Business Management, 4(16), 3556-3563 (2010).

13. Cheong, J. H., Park, M. C.: Mobile Internet acceptance in Korea. Internet Research, 15(2), 125-140 (2005).

14. Dancey, C. P., Reidy, J.: Statistics without Maths for Psychology. Pearson Education (2007).

15. Das, C.: A study on validity of modified technology acceptance model of mobile. Accessed: www.ghimr.edu.in/.../ValidityOfModifiedTechnology.pdf (2011).

16. Dwivedi, Y. K., Wastell, D., Laumer, S., Henriksen, H. Z., Myers, M. D., Bunker, D., Elbanna, A., Ravishankar, M. N., Srivastava, S. C.: 'Research on Information Systems Failures and Successes: Status Update and Future Directions'. Information Systems Frontiers, 17(1), 143-157 (2015).

17. Dwivedi, Y. K, Choudrie, J., Brinkman, W. P.: 'Development of a survey instrument to examine consumer adoption of broadband'. Industrial Management and Data Systems, 106(5), 700-718 (2006)

18. Ethos Interactive.: Internet and mobile users in Saudi Arabia KSA. Available on: http://blog.ethosinteract.com/2012/02/06/Internet-user-in-saudi-arabia-ethosinteractive. Accessed: 03.02.15 (2012).

19. Featherman, M. S., Pavlou, P. A.: Predicting e-services adoption: a perceived risk facets perspective. International Journal of Human-Computer Studies, 59(4), 451-474 (2003).

20. Fogelgren-Pedersen, A.: The mobile Internet: The pioneering users' adoption decisions. In System Sciences, 2005.HICSS'05.Proceedings of the 38th Annual Hawaii International Conference. (p. 84). IEEE (2005).

21. Franzosi, R.: From words to numbers: Narrative, data, and social science. Vol. 22. Cambridge University Press (2004).

22. Hailin, S.: Mobile Internet experience research based on TAM. In E-Product, EService and E-Entertainment (ICEEE), 2010International Conference. (pp. 1-4). $\operatorname{IEEE}(2010)$. 
23. Hsiao, K. L.: Android smartphone adoption and intention to pay for mobile Internet: Perspectives from software, hardware, design, and value. Library Hi Tech, 31(2), 3 (2013).

24. Hsu, H. H., Lu, H. P., Hsu, C. L.: Adoption of the mobile Internet: An empirical study of multimedia message service (MMS). Omega, 35(6), 715-726 (2007).

25. Huang, J., Liu, D.: Factors influencing continuance of mobile virtual community: Empirical evidence from China and Korea. In Service Systems and Service Management (ICSSSM), 2011 8th International Conference. (pp. 1-6). IEEE (2011).

26. Jiang, P.: Adopting mobile Internet: A demographic and usage perspective. International Journal of Electronic Business, 6(3), 232-260 (2008).

27. Karaiskos, D. C., Kourouthanassis, P., Lantzouni, P., Giaglis, G. M., Georgiadis, C. K.: Understanding the adoption of mobile data services: Differences among mobile portal and mobile Internet users. In Mobile Business, 2009. ICMB 2009. $8^{\text {th }}$ International Conference. (pp. 12-17). IEEE (2009).

28. Mallat, N., Rossi, M., Tuunainen, V. K., Oorni, A.: The impact of use situation and mobility on the acceptance of mobile ticketing services. In System Sciences, 2006. HICSS'06. Proceedings of the 39th Annual Hawaii International Conference. (Vol. 2, p. 42). IEEE (2006).

29. Rogers, E. M.: Diffusion of innovations. $4^{\text {th }}$ edn. New York: The Free Press (1995).

30. Shin, D. H.: The evaluation of user experience of the virtual world in relation to extrinsic and intrinsic motivation. International Journal of Human-Computer Interaction, 25(6), 530-553 (2009).

31. Slade, E, Dwivedi, Y. K., Piercy, N. L., Williams, M. D.: 'Modeling consumers' adoption intentions of remote mobile payments in the UK: Extending UTAUT with innovativeness, risk and trust,' Psychology \& Marketing. 32(8), 860-873 (2015).

32. STC Group.: ICT in Saudi Arabia: A socio-economic impact review. Available on: http://www.enlightenmenteconomics.com/Reports/assets/ICTinSaudi\%20Arabia. pdf. Accessed: 05.02.15 (2011).

33. Thong, J. Y., Hong, S. J., Tam, K. Y.: The effects of post-adoption beliefs on the expectation-confirmation model for information technology continuance. International Journal of Human-Computer Studies, 64(9), 799-810 (2006).

34. Thong, J. Y., Venkatesh, V., Xu, X., Hong, S. J., Tam, K. Y.: Consumer acceptance of personal information and communication technology services. Engineering Management, IEEE Transactions, 58(4), 613-625 (2011).

35. Venkatesh, V., Thong, J., Xu, X.: Consumer acceptance and use of information technology: Extending the unified theory of acceptance and use of technology. MIS Quarterly, 36(1), 157-178 (2012).

36. Venkatesh, V., Morris, M. G., Davis, G. B., Davis, F. D.: User acceptance of information technology: Toward a unified view. MIS Quarterly, 425-478 (2003).

37. Williams, M. D., Rana, N. P., Dwivedi, Y. K.: 'The Unified Theory of Acceptance and Use of Technology (UTAUT): A Literature Review'. Journal of Enterprise Information Management, 28(3), 443-488 (2015).

38. Wiratmadja, I. I., Govindaraju, R., Athari, N. The development of mobile Internet technology acceptance model. In Management of Innovation and Technology (ICMIT), 2012 IEEE International Conference on. (pp. 384-388). IEEE (2012).

39. Wu, J. H., Wang, S. C.: What drives mobile commerce? An empirical evaluation of the revised technology acceptance model. Information \& Management, 42(5), 719729 (2005).

40. Zhou, T.: Examining location-based services usage from the perspectives of Unified Theory of Acceptance and Use of Technology and privacy risk. Journal of Electronic Commerce Research, 13(2), (2012). 